WIDER Working Paper 2017/156

New technologies create opportunities

Sally Murray*

July 2017

United Nations University World Institute for Development Economics Research

\title{
wider.unu.edu
}


Abstract: This paper argues that new technologies-for communication, such as mobile phones and the internet, but also for manufacturing, agriculture, energy, and transport-have the potential to bridge many of the productivity gaps between sub-Saharan Africa and more advanced developing and developed countries. Technology can help to overcome distances between producers and consumers, knowledge and skills gaps, and energy shortfalls, and can bring down the costs of living to make wages competitive. However, new technologies will not deliver these gains unaided: supportive policies are required to create an environment where these new technologies can deliver on their potential.

Keywords: Africa, industrialization, technology

JEL classification: 014, 025, 033, 055

Acknowledgements: The author would like to thank Richard Newfarmer for his many helpful contributions to and overall guidance on this piece.

* International Growth Centre, Kigali, Rwanda, sally.murray@theigc.org

This study has been prepared within the UNU-WIDER project on 'Industries without smokestacks', which is part of a larger research project on 'Jobs, poverty and structural change in Africa'.

Copyright (C) UNU-WIDER 2017

Information and requests: publications@wider.unu.edu

ISSN 1798-7237 ISBN 978-92-9256-382-0 https://doi.org/10.35188/UNU-WIDER/2017/382-0

Typescript prepared by Merl Storr.

The United Nations University World Institute for Development Economics Research provides economic analysis and policy advice with the aim of promoting sustainable and equitable development. The Institute began operations in 1985 in Helsinki, Finland, as the first research and training centre of the United Nations University. Today it is a unique blend of think tank, research institute, and UN agency — providing a range of services from policy advice to governments as well as freely available original research.

The Institute is funded through income from an endowment fund with additional contributions to its work programme from Denmark, Finland, Sweden, and the United Kingdom.

Katajanokanlaituri 6 B, 00160 Helsinki, Finland

The views expressed in this paper are those of the author(s), and do not necessarily reflect the views of the Institute or the United Nations University, nor the programme/project donors. 
Manufacturing has been declining in world gross domestic product (GDP), and most markedly in the GDP of countries with historically less advanced manufacturing sectors, such as those of subSaharan Africa. Rodrik (2016: 3) argues that this 'premature deindustrialization' of sub-Saharan Africa 'could well remove the main channel through which rapid growth has taken place in the past', making strong growth extremely difficult to sustain. In sub-Saharan Africa, Rodrik argues that weak comparative advantage in manufacturing is to blame (when combined with those countries' openness to global trade).

Sub-Saharan Africa's weak comparative advantage in manufacturing is a child with many parents: small isolated, markets distant from major centres, low labour productivity associated with education levels and low capital stock, and high energy prices, among others (see Newman et al. 2016).

This paper explores the opportunities for new technologies to raise the comparative advantage of manufacturing as well as agriculture and services sectors, and the quality of life at any given level of income, in sub-Saharan Africa. It posits that the ongoing technological revolution-in communication technologies such as mobile phones and the Internet, but also in manufacturing, agriculture, energy, and transport technologies — can bridge many of the productivity gaps between sub-Saharan Africa and more advanced developing and developed countries. Technology can help to overcome distances between producers and consumers, knowledge and skills gaps, and energy shortfalls, and bring down the costs of living to make wages competitive. However, new technologies will not deliver these gains unaided: strong political leadership and supportive policies are required to create an environment where new technologies can deliver on their potential.

Technology is rapidly increasing connectivity, within and between countries. The past two decades have seen a rapid improvement in access to communication, through technologies such as mobile phones and the Internet. In developing countries, this is not only providing citizens with more and better information; it is also allowing firms to access more customers and suppliers. The costs and barriers to receiving payment for goods and services, and to sending, saving, and borrowing money, have also been hugely reduced with the explosion of mobile money, mobile banking, and e-payment platforms, and the gradual integration of these platforms across networks and national borders.

This growth in communication technologies has perhaps been the best-documented channel for technology's impact in sub-Saharan Africa, but a broader set of technologies offer serious potential to raise labour productivity. Additive manufacturing (3D printing) can overcome shortages in local skills and supply chains, so more complex tasks can be completed in less developed locations. Accelerated investment in agricultural research and more favourable legislative environments for genetically modified crops have the potential to multiply yields and improve resilience to risks such as climate change. By relieving the intense pressures on food prices, this could reduce living costs and vulnerability considerably, bringing down wages and improving workers' health and wellbeing. Falling data and device costs are also gradually granting low-income and isolated people access to international-standard information and educational materials. For citizens who are highly literate, and who are fluent in a major international language, these opportunities can be transformative, thanks not only to informal sources of information such as Wikipedia, but also to structured learning of extremely high standards through platforms such as edX, Code Academy, Coursera, Duolingo, and Khan Academy. 
The high cost of power has been a major impediment to firms in sub-Saharan Africa, from smaller firms looking to expand, to international investors considering where to locate factories. Yet technological advances are also cutting the costs of power in a way that is game-changing. Although hydropower currently dominates the renewables landscape in sub-Saharan Africa (84 per cent of renewable production), the costs of solar have been falling at 10 per cent per year (faster than any other energy technology) so that new solar capacity is already cheaper than coal in more than 30 countries, with prices still falling. Large solar plants are planned, or already feeding grids, in many sub-Saharan African countries, while off-grid solar is increasingly enabling remote firms and poor households to access reliable power.

With the right policies to nurture and take advantage of these opportunities (discussed in this paper), sub-Saharan Africa could boast more efficient access to inputs and consumers, an increasingly skilled and healthy workforce with competitive wages, and competitive power costs. In those circumstances, there would be considerable scope for optimism about sub-Saharan African countries 'bridging the productivity gap' and offering comparative advantage in manufacturing, as well as other innovative sectors, to curtail premature deindustrialization.

\section{Overcoming distance}

\subsection{E-commerce to boost small to medium-sized enterprises' growth and exports}

An entrepreneur in sub-Saharan Africa may have an idea enabling her to produce an in-demand product efficiently; but how do potential customers find out about that product, place an order, make the payment, and overcome the logistics to have it delivered? Especially for small to mediumsized enterprises (SMEs), the high 'search costs' for consumers to find products, and the transaction costs of payment and shipping, are a serious deterrent to innovation and investment in sub-Saharan Africa.

Evidence from Asia, Europe, and North America, however, suggests that e-commerce platforms reduce search and transaction costs for small firms considerably. They provide consumers with fairly equal access to product information regardless of the seller's location or size, and offer simplified payment and logistics services designed for novices. Lendle and Vezina (2015) compared online sales through eBay with offline sales (recorded by World Bank data), finding that firms of all sizes sold to far more countries when selling online. In fact, online sales behaved almost as if borders and distance introduced no transaction or search costs at all. The researchers constructed a model to estimate the number of export destinations a firm would reach if trade (borders and distance) were frictionless (the green curve in Figure 1). While the offline sales deviated quite far from the model (red dots), online sales (blue dots) performed almost as predicted by this 'zero trade frictions' model. 
Figure 1: Online traders reach more export destinations

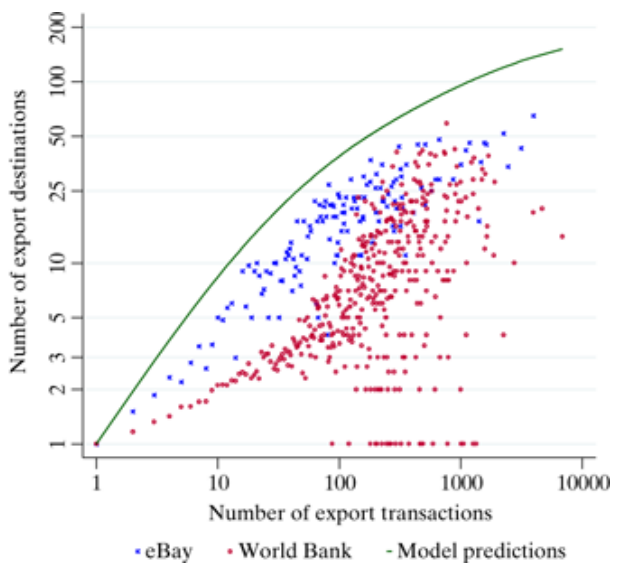

Source: Lendle and Vezina (2015).

E-commerce is an expanding sector internationally. Ten to 15 per cent of sales in the US and Europe are now online (ITC 2015), while business-to-consumer online sales were equivalent to approximately 1.6 per cent of global GDP in 2015 (Statista 2017). Online marketplaces such as eBay, Amazon, AirBnB, and Alibaba, and online and mobile payment platforms such as PayPal and WorldRemit, reduce the information and communications technology (ICT) skills and logistics knowledge needed to sell (and buy) online and across borders.

Sub-Saharan Africa suffers certain more pronounced barriers to e-commerce. Many firms still lack access to affordable, fast, reliable Internet, while many banks on the continent are unsophisticated, restricting online banking to premium customers or not providing internationally recognized credit or debit cards. Computer literacy, as well as literacy in major international languages, also remains low in many countries, meaning many entrepreneurs struggle to navigate global e-commerce sites and communicate with customers. National postal services in sub-Saharan Africa also tend to be slow and unreliable, and in many cases do not extend beyond centralized post office box systems in major cities, while private couriers can be prohibitively expensive, and customs procedures complicated or corrupt.

But despite these challenges, e-commerce is already taking off in a serious way in sub-Saharan Africa. In South Africa, three of the top 25 most visited websites are banks, and five are online marketplaces. In December 2016, global e-commerce site Amazon was the 13th most visited website in Uganda and South Africa. Africa has also bred its own online marketplaces. Jumia, founded in 2012, had over $\$ 60 \mathrm{~m}$ invested in it by 2016, including from Goldman Sachs, Axa, Orange, and MTN. Jumia started in Nigeria, but by 2017 over half a million African firms were using it, and it sees some activity in most countries on the continent; for example, it is the 11th most popular site in Kenya (Alexa 2017). Jumia itself is not without strong competitors, with Konga battling hard for the Nigerian market, Souq dominating in Egypt, and more specialized platforms such as Kasha, which sells culturally sensitive women's hygiene and contraceptive products in Rwanda.

The case of China's Alibaba group helps to highlight the potential of e-commerce for the growth of domestic and international trade, and the steps needed to realize this potential. The Alibaba group encompasses business-to-business, business-to-consumer, and consumer-to-consumer online sales platforms. Firms of all sizes participate, and sell both within and outside China. To understand the scale of Alibaba's success, consider that in 2013, Alibaba's consumer-to-consumer marketplace, Taobao, accounted for 60 per cent of all parcels delivered in China (The Economist 2013b). In 2014, it was listed on the New York Stock Exchange with the highest-ever initial price 
offering (valuing the company at US $\$ 167.6$ billion) (Chen 2014). Although most popular for domestic sales within China, firms on Alibaba can export to over 200 countries, and can export from any country in the world; indeed, Alibaba's AliExpress is already the most popular ecommerce site in Russia (Jingjing 2017).

Alibaba's founder, Jack Ma, has opined that while the first 20 years of the technological revolution were characterized by advances in technological knowledge, the next 30 years will be characterized by a revolution in technological inclusion - key for empowering businesses and entrepreneurs in less developed countries (Sangwongwanich 2016).

\subsection{Transport innovation for e-commerce (and broader export competitiveness)}

Alibaba's success in China is in part due to eBay's failure-its poor sensitivity to Chinese consumers' preferences and, crucially, its failure to invest in overcoming China's challenging transport logistics.

One ingredient that must be in place for successful e-commerce is the affordable and reasonably fast transport of goods from firms to consumers. Alibaba took bold steps to almost unilaterally overcome China's challenging logistics environment. In May 2013, it launched Cainiao (in which Alibaba owns 48 per cent of shares), which uses a sophisticated software platform to coordinate package deliveries between several affiliated logistics operators. In 2016, over 33 million packages were processed through Cainiao each day (three quarters of all packages delivered in China), and Cainiao directed the work of 1.7 million delivery and warehouse personnel and 180,000 delivery stations. As well as coordinating other providers, Cainiao also directly owns parts of the supply chain, including 150 warehouses in China and 10 in the US, to ensure even faster delivery of popular items (Cainiao Network 2016).

Competition over international e-commerce space is driving further innovation. Amazon, for example, recently introduced five-day shipping of any small packages (up to $1.7 \mathrm{~kg}$ ) from China to Amazon Prime members, compared with the two to four weeks offered by Cainiao (Soper 2016). The US Postal Service and Hongkong Post have also partnered to offer ePacket, a service for tracked and faster delivery of small packages (up to $2 \mathrm{~kg}$ ) from China or Hong Kong to the US. Between healthy markets of producers and consumers, there are strong incentives to build logistical bridges to facilitate e-commerce.

Alternative vehicles offer a more 'wild card' opportunity to raise the reach and efficiency of logistics systems. Looking to overcome its hilly landscape and poor rural road network, in October 2016 Rwanda began using drones to transport blood and other urgent medical supplies to rural hospitals. Health workers order supplies through text messages, after which, within minutes, a drone is loaded with their order and flies to them at $100 \mathrm{kmph}$. The packages are dropped from the sky at the delivery location, with small parachutes to soften the landing. The initial drones deliver up to a $75 \mathrm{~km}$ radius, thus covering most of the country from a single base.

The company that designed and manages the drones, Zipline, does not publish the costs of the journeys, suggesting they are not yet commercially viable for a broader range of uses. However, if these prototypes are reasonably cost-effective for transporting blood in Rwanda, they may be appropriate for other items with very high value-to-weight ratios that must be delivered in a timely fashion. Drones may be efficient for a wider range of goods over time, as innovations reduce costs. Zipline's stated vision is to have a drone network across Africa, focused on delivery to and from the areas worst served by roads and paths. 
Drone delivery did not start in Rwanda simply because of its weak road network. A key reason is regulation: Rwanda is particularly committed to promoting science and innovation, and invested in carefully updating its aviation regulations to make Zipline's activities possible. Regulating for cross-border drone delivery (for example, for Rwanda to export to less accessible parts of the Democratic Republic of the Congo, or import spare parts quickly from Uganda) could be transformational, but is also a major challenge, especially where people harbour concerns about drones' use for surveillance. The case demonstrates, however, that countries can proactively attract such innovations and investments by making a friendly and sound regulatory environment and communicating their openness and commitment.

It is important to note that-as with the limited radius of drone deliveries-innovative technologies can only take African logistics so far. Traditional physical transport infrastructure will remain critical. Alongside its e-commerce revolution, China invested heavily in more traditional overland transport infrastructure-nine per cent of its GDP throughout the 1990s and 2000s, while most emerging economies invested only two to five per cent. Every year, 1.2 billion tons are transported on China's waterways, 50 times the amount imported to East Africa's main port, Mombasa, in 2015 (Northern Corridor Transit and Transport Coordination Authority 2016). Africa has relatively few canals or inland waterways navigable with large ships, while 10,000-ton ships can now reach 1,000 km up the Yangzte, and 1,000-ton ships can go a further 1,200 km upstream. China's Grand Canal is almost 2,000 km long, and links 17 cities and five rivers. While Africa's railway network remains limited in reach and plagued by different gauges, China's railways transport 3.3 billion tons of cargo annually, and $20,000 \mathrm{~km}$ of high-speed trains (travelling at up to $350 \mathrm{kmph}$ ) operate between many major cities (with 15,000 km more planned by 2025) (The Economist 2017). These investments are plugging more remote towns and workers into production value chains, helping to keep wages and land prices competitive.

Efforts to improve the efficiency of overland transport in Africa have been important, but less remarkable. In East Africa, institutional improvements such as the harmonization of procedures and customs upgrading, and stronger policing of corruption, have helped to reduce the time taken for a container to reach Kigali from Mombasa from 30 to 11.4 days in the past decade. But costs have fallen little - in 2016, transporting a container from Mombasa to Kigali cost US $\$ 4,700$, a figure little changed since 2014, and approximately twice the cost to ship the container as far as the UK (Northern Corridor Transit and Transport Coordination Authority 2016). An East African standard gauge railway project is underway and planned to connect Kampala, Juba, Kigali, and Bujumbura to Mombasa port (Parke 2016). Financing is far more challenging when benefits are shared between many countries, however. By mid-2017, it is planned to connect Mombasa port to Nairobi, reducing journey times from 12 to four hours for that leg, and able to carry 25 million tons per year. But the gap with China still can hardly be overstated.

Exploiting new logistics technologies and e-commerce will be most powerful against a background of solid, 'boring' infrastructure (Frazer 2016) such as roads, ports, borders, and railways. This reflects a broader lesson for the 'technology revolution': in the words of H. Jackson Brown, Jnr, 'opportunity dances with those who are ready on the dance floor'. Being ready on the dance floor means investing heavily to get 'the basic foundations' in place so that technology can then take things to the next level. Technology can only help to optimize what it finds.

Governments can also help to unlock the promise of e-commerce through standards harmonization. Standards often preclude trade of certain goods and services between neighbouring countries in Africa, while meeting the requirements of strict importers such as the European Union (EU) has been extremely difficult for many industries. Simplified and harmonized legislation, clearly communicated to SMEs, is the first step. Governments can also provide technical support 
for firms to achieve required standards or accreditation. These steps can enable SMEs to take better advantage of e-commerce to export regionally and internationally.

It should also be noted that certain weaknesses of Africa's transport systems also constitute a strength for e-commerce when only the (more limited) domestic market is considered. The coCEO of Jumia, Jeremy Hodara, stated that 'ultimately, e-commerce is going to exceed bricks and mortar retail [in Africa]_similar to how mobile phones eclipsed landlines' (Babej 2014). This is thanks to the poor design and management of many cities and transport networks:

In Lagos there are two malls serving 20 million people... [T] he city is extremely jammed so it's hard to get to a mall. As a result, when you want to buy phones, shirts, or shoes, you often have to travel abroad... In Africa, organized retail will never be as strong as in the US... so it stands to reason that the potential share of online retail can be significantly higher in Africa... In Nigeria, we now have more than 500 motorbikes and trucks that deliver to our customers in the eight biggest cities of the country. Our delivery fleet is larger than UPS, Fedex and DHL in Nigeria... Simply put, we believe we need to control the value chain from A-Z (Babej 2014).

While most American or European consumers can quite easily shop in offline stores, sub-Saharan African consumers must always overcome their small local markets and weak domestic transport sectors; e-commerce firms can gain a competitive edge through marginal improvements to the ease of finding and receiving products from within the country.

\subsection{Language and cultural barriers to e-commerce}

As well as investing in understanding and tailoring its service for China's logistics, Alibaba also tailored its site's style for Chinese consumer preferences. Currently, few African firms are represented on Alibaba.com, but this may be in part for similar reasons-more tailored platforms are needed. Indeed, Africa-specific e-commerce sites are already emerging in a big way, with Konga in Nigeria, Souq in Egypt, and Jumia in several countries in West, North, and East Africa.

The proliferation of platforms may indicate a challenge for e-commerce in Africa. Do the more pronounced differences in language, culture, and skills across countries and regions mean that Africa's marketplaces will remain more fractured, denying the continent a unified 'shopfront' and a streamlined logistics platform to connect it to the outside world and internally, in the way that Alibaba has connected China?

\subsection{Internet costs}

Another major barrier to e-commerce in sub-Saharan Africa has been simply the high cost and poor quality of data and smartphones. Though services differ substantially by country and operator, Africa has some of the highest Internet costs and worst coverage and speed in the world (The Economist 2013a). Average monthly fixed broadband costs are estimated to be 64 per cent of monthly income in Africa, compared to 1.7 per cent in developed countries (Broadband Commission for Sustainable Development 2016), while (the more popular) mobile broadband prices in developing countries are twice as high as those in developed countries (International Telecommunications Union 2015). So far, only a quarter of people in Africa have smartphones. 


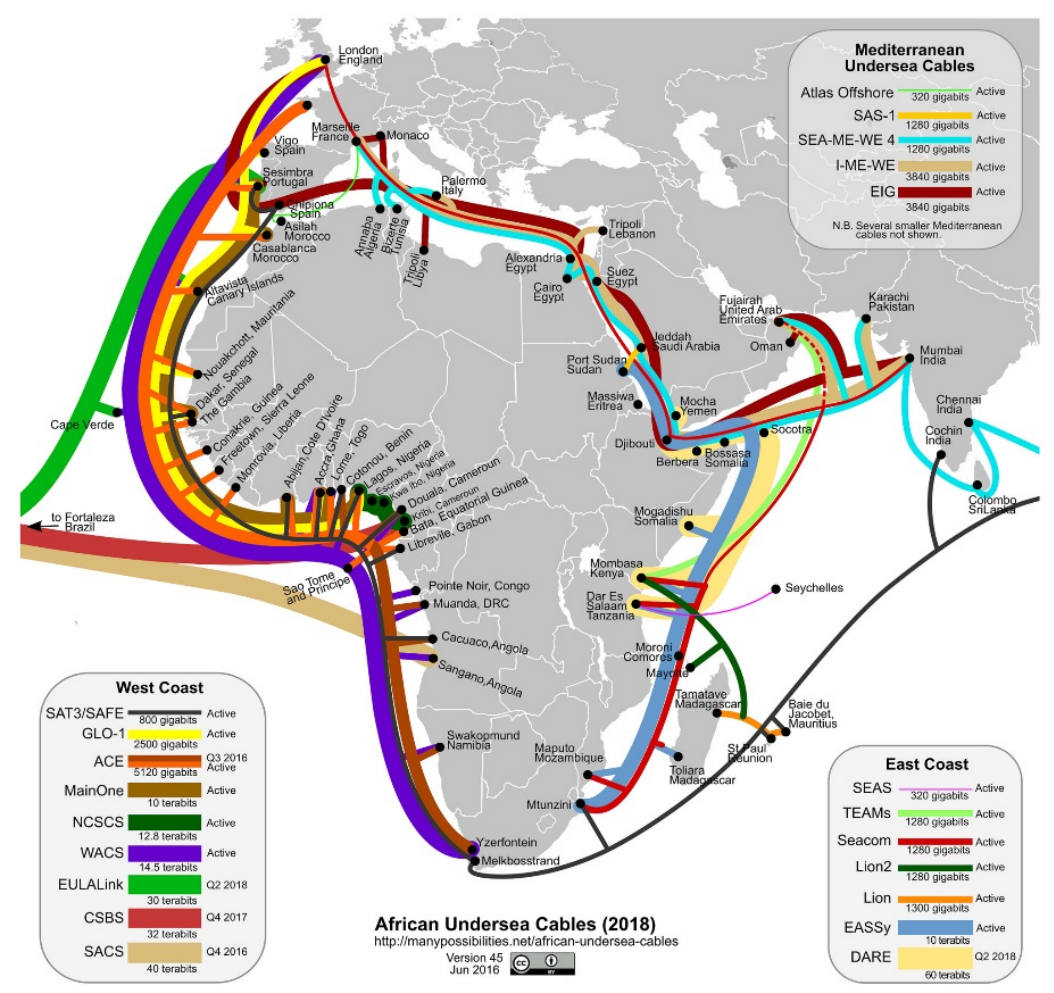

Source: Song (2016) CC BY 2.0.

However, data costs are forecast to come down dramatically, with a surge in data supply exceeding that in demand. The data capacity of satellites quadrupled from 2006 to 2016, to 1.5 terabytes per second. Eight terabytes per second is forecast by 2020 (Scaturro 2016). Some satellites orbiting over Africa already have 80 per cent spare capacity, which firms such as Facebook and Google are looking to channel to provide affordable mass Internet access. Coastal areas will benefit from the completion of further high-speed Internet cables (Figure 2). For isolated areas, initiatives such as Facebook's internet.org (providing rural Internet access through lasers and unmanned solar aircraft), Google's Project Loon (using balloons in the upper atmosphere), and hundreds of microsatellites launched by Tesla aim to bring data costs down even further, while rural power initiatives such as solar home systems make appliance charges affordable for more firms and customers. E-commerce platforms are making their own efforts to ensure data costs for their sites are bearable. Jumia, for example, is part-owned by major data providers (MTN, Millicom, and Orange) in most countries where it operates, facilitating access to consumers. In 2014, the average cost of mobile broadband ${ }^{1}$ fell by 40 per cent in least developed countries (International Telecommunications Union 2015), and several network operators in the region recorded a 50 per cent increase in data usage in 2015 (GSMA Intelligence 2016).

Governance quality and will to create an enabling environment for ICT is crucial to make sure citizens and firms enjoy these gains (Frischtak 2017). The World Bank reports that 18 per cent of Rwanda's population used the Internet in 2015, compared with just 4.9 per cent in neighbouring Burundi; yet location, topography, and incomes are similar in each country. In Kenya 45.6 per cent of citizens use the Internet, compared with just 11.6 per cent in its neighbour Ethiopia (World

\footnotetext{
${ }^{1}$ This is based on the example of $500 \mathrm{MB}$ of prepaid handset-based data.
} 
Bank 2017). Such divergent access in superficially similar countries must be attributed to governance and supportive policy.

The explosion in mobile phone ownership in sub-Saharan Africa is well documented: from 2010 to 2015 there was a 10 per cent annual growth in unique mobile subscribers in Africa; penetration in Africa was 46 per cent by 2015, which was the global penetration rate in 2010 (now 65 per cent) (GSMA Intelligence 2016). Smartphone prices have now begun to plummet, too; average selling prices in Africa were US $\$ 230$ in 2012, but just US $\$ 160$ by 2015, and smartphones below US $\$ 50$ are now available (GSMA Intelligence 2016). Meanwhile, functionality improves exponentially. Smartphones are thus also being adopted at progressively lower income levels (Figure 3). When combined with cheap data, this can deliver Internet access to a rapidly widening circle of customers and firms.

Figure 3: The global gap in smartphone access is narrowing

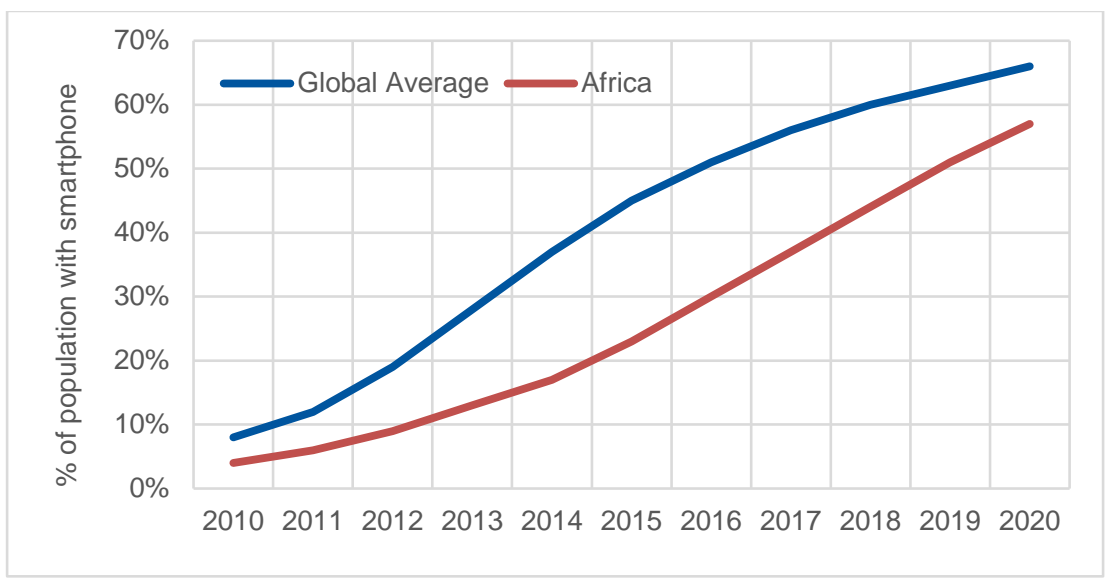

Source: author's illustration based on data from GSMA Intelligence (2016).

\subsection{Mobile payment technologies}

The vast majority of banks in sub-Saharan Africa are slow and expensive to deal with, and in rural areas they are also extremely dispersed. This has historically made it even harder to trade domestically and internationally, and is a particular barrier to e-commerce.

Partially as a result of these failures of traditional banking, mobile bank accounts have exploded in popularity and are becoming increasingly sophisticated. In sub-Saharan Africa, 34 per cent of adults have mobile money accounts, and the number of agents and accounts grew by 30 per cent in 2015 alone. M-Pesa, the most successful product on the continent, was launched as recently as 2007 , but by 2016 , US $\$ 32.5$ billion was being transferred over the platform in Kenya alone (compared with Kenya’s \$63.4 billion GDP) (Central Bank of Kenya 2017).

Using mobile phones, a firm can receive payments from customers; pay employees, suppliers, and often taxes; save; and increasingly, even develop a credit history and take out loans. Many of these services were inaccessible to small firms and lower-income individuals a few years ago. As smartphone penetration rises, and mobile payment services and online marketplaces are increasingly linked, SMEs will be able to sell online and accept international payments into their mobile money accounts, making the logistics of exporting much easier to take on.

Costs of international payments through mobile money are on average half of those through more traditional channels such as banks, money transfer operators, and post offices. Mobile transfers constituted just 1.2 per cent of money sent across borders in 2015 , but this volume grew by 50 per 
cent in the same year (GSMA 2016). As well as cost savings, mobile money is much more convenient, enabling both sender and buyer to make transfers without travelling to an agent.

The key challenge for mobile money transfers, both internationally and domestically, is no longer a technological barrier, but firms' and countries' decisions to ensure interoperability: most traditional and e-payment platforms cannot communicate with one another, meaning that users must be on the same network and platform in order to trade.

Certain mobile network operators are working towards interoperability. In 2015, Vodaphone and MTN announced they would connect their respective M-Pesa and MTN Money services across Kenya, Tanzania, the Democratic Republic of the Congo, Mozambique, Uganda, Rwanda, and Zambia. Traditional international money transfer operators such as Western Union are also beginning to allow transfers to mobile money accounts, while dedicated platforms for (international) bank-to-mobile-money transfers are also being created: anyone with a Visa card or MasterCard can send money to almost any mobile money customer through services such as WorldRemit or PayPal's Xoom. Some of these systems are still quite basic-for example, not allowing identifiers or reasons to be sent to the recipient-but this results from their newness rather than deep technical limitations. Considering that the largest mobile money platform, MPesa, only launched in 2007, it is encouraging that such strong steps towards interoperability across operators, mediums, and countries have already been implemented or initiated.

Even if payment platforms are integrated, selling and remitting money across borders will remain difficult if communication across those borders remains expensive. East Africa therefore also launched a 'one network area', through which roaming charges are abolished throughout the East African community. The World Bank estimates that this move almost immediately increased the minutes of phone calls between Kenya and Rwanda by over 950 per cent (Kelly and Kemei 2016), implying a high latent demand for cross-border phone calls, and suggesting that roaming charges are holding back the spread of ideas and trade of goods and services across (the vast majority of the world's) borders where they are still in place.

Mobile money is not only helping firms to trade; it is also, of course, facilitating remittances. In 2015, international remittances to developing countries were higher than all international aid. Domestic remittances seem to be even larger: a 2015 study found domestic remittances in South Africa were five to seven times higher than international remittances, and equivalent to four per cent of GDP (TechnoServe 2016). Mobile money may also thus raise the attractiveness of sending family members to work in cities, potentially reducing reservation wages and raising labour productivity.

\subsection{Online service sales}

The weaknesses of traditional transport infrastructure have caused many African countries to turn towards service export opportunities. Services were not historically 'tradeable', and in sub-Saharan Africa were typically limited to very local, low-productivity 'street corner' activities. However, ecommerce is expanding opportunities for the export of services through business process outsourcing and freelance opportunities such as copywriting, web design, journalism, software development, 'low-skill' rote tasks, and virtual office assistance.

To illustrate the concept, consider Amazon's Mechanical Turk. This is an online platform for firms and individuals to recruit remote workers to complete tasks on a freelance basis. Typical tasks include responding to surveys, processing photos and videos, cleaning and verifying data, finding information, and writing content for websites. Although tasks on Mechanical Turk tend to be fairly 
simple, rote, and unskilled (hence 'mechanical'), at present 80 per cent of its freelancers are based in the US, and the vast majority of the remainder are in India. Some popular online tasking platforms, such as Fancy Hands, explicitly advertise that their online assistants are US college graduates. China, with a large domestic market and its own languages, has seen the growth of its own dedicated online tasking sites: Witmart, for example, has over seven million registered freelancers in China, operating mostly in Mandarin. Why are these task sites not more accessible to international workers, and why in particular do we see so few online task providers from Africa?

Literacy and fluency in an international language are necessary in most cases. Literacy rates in most sub-Saharan African countries are still comparatively low, and despite colonial language legacies, many more citizens are still fluent in only local or regional languages. A shared cultural understanding and exposure to 'modern' workplaces may also be required to correctly interpret and execute many tasks. Cultural understanding ought to be teachable, but highly decentralized platforms such as Mechanical Turk cannot be expected to do the teaching.

If sub-Saharan Africa can improve broader literacy and fluency in international languages, more traditional business process outsourcing units such as call centres could shift from India. These are already fairly common in South Africa, and are beginning to open in most countries on the continent as Asian wages climb. Some firms opening call centres in Africa have noted that customers find African accents easier to understand than Indian, encouraging them to expand operations. The next section of this paper discusses how new technologies also create opportunities for certain constituencies in sub-Saharan Africa to develop more marketable skills, including for the online and offline services sectors.

\subsection{Summary on overcoming distance}

E-commerce is promising for Africa, whose firms have historically struggled to reach consumers and inputs. It removes geographical barriers to information about products, launching firms onto a global marketplace, while facilitating small and large firms to overcome payment and logistical challenges. By improving consumers' information about products, e-commerce also creates incentives - to which firms and governments are already responding-to solve remaining challenges to trade, such as the observed vertical integration of logistics by Alibaba and Jumia. Meaningfully exploiting the opportunities of e-commerce, however, requires governments to step up to this mark at the national and regional levels. It demands a strong and affordable Internet infrastructure; literate, computer-literate entrepreneurs; harmonized payment platforms; and the 'boring' foundations of efficient overland transport, reduced non-tariff barriers such as standards and customs procedures, and functional postal systems. The commitment of national and regional governments to prepare this 'runway' will determine the ability of e-commerce to take off on the continent. 
Competitive low-skill wages are key to manufacturing productivity. At face value, these are cheaper in sub-Saharan Africa than emerging Asia; and despite starting from a higher base, wage growth has also been higher in Asia (Figure 4).

Figure 4: Average wage growth in Asia vs Africa, 2006-2015

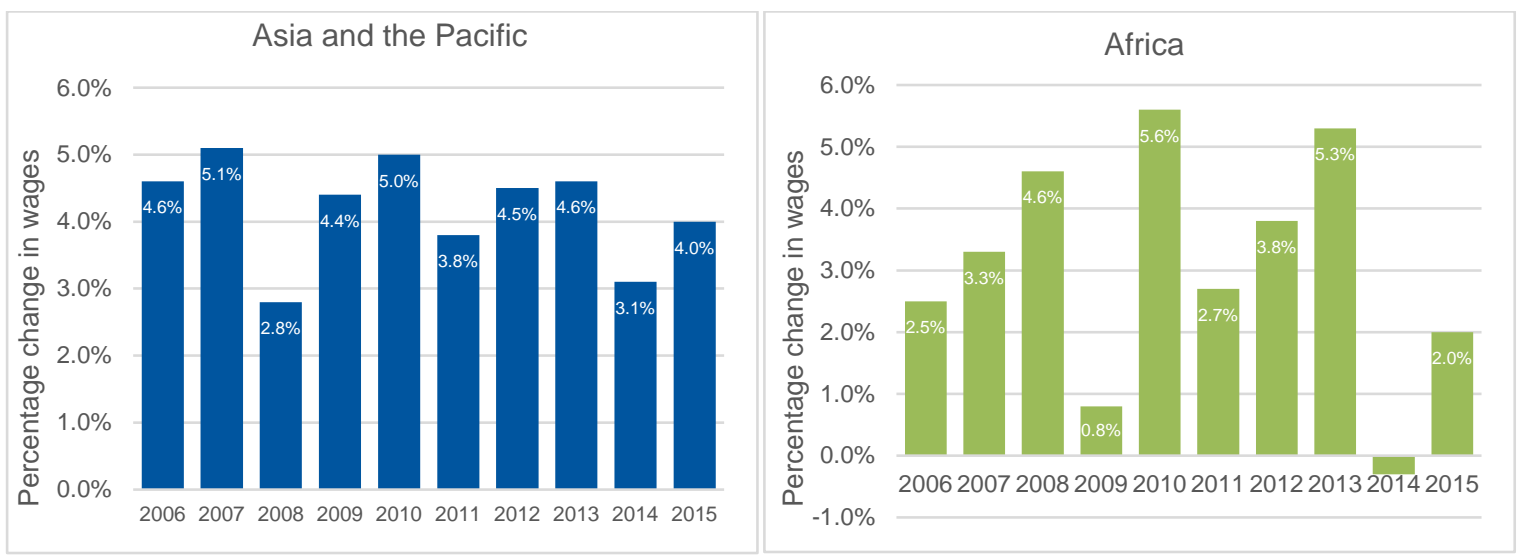

Source: author's illustration based on data from ILO (2016).

Living costs in sub-Saharan Africa, however, are high relative to its industrial development and human capital. Asia experienced its off-farm and urbanization growth during and following the 'green revolution', through which new agricultural technologies freed up farm labourers and produced higher yields to bring down food prices and keep wages low. Africa has yet to enjoy such an explosion in agricultural productivity, and also suffers high housing and transport costs and weak education systems. This places upwards pressure on wages, and limits the competitiveness of African workers.

New technologies offer chances for more firms in Africa to flourish in spite of workforce weaknesses, while others can help to raise workers' human capital, and reduce living and wage costs, to make workers more competitive.

\subsection{Raising human capital}

Given transport challenges, many African governments see a large portion of future economic growth in the services sector, and in goods with high value-to-weight ratios. For both sectors, human capital is typically crucial. Call centre staff in India often have undergraduate degrees or higher, and their language skills must be impeccable. New services tasks such as programming require strong technical skills, while higher value-added manufacturing often also requires technical expertise.

Sub-Saharan African countries, however, have some of the lowest literacy and education levels in the world. Between 10 and 40 per cent of adults in most sub-Saharan African countries are 'illiterate', despite this measuring only very basic literacy ability (whether the respondent can read and write a basic sentence about their lives). Although primary school enrolment is almost 100 per cent in most developing countries, the quality of education children receive is extremely poor: an India-wide survey in 2005 found that 44 per cent of children aged seven to 12 could not read a basic paragraph, and 50 per cent could not do a simple subtraction; similar results are found in many countries in sub-Saharan Africa (Banerjee et al. 2007). Only approximately seven per cent of 
adults have degrees, and even among those who do, the skills transferred during higher education often do not leave graduates job-ready (British Council 2014). There is a vicious circle of poorly educated children becoming poorly educated parents and teachers, unable to pass adequate knowledge and skills on to the next generation, and with grossly insufficient resources invested to break the cycle. Whereas countries in the Organization of Economic Cooperation and Development (OECD) spend around US $\$ 7,000$ per primary pupil per year, many African countries spend less than one hundredth as much (OECD 2016). How, in such an environment, can African economies possibly develop the human capital required for service-sector-led growth?

\section{E-learning for basic skills}

Breaking the cycle of poor education is difficult when countries' financial resources are so stretched. But the costs to access information and learning tools may be falling with the growth of cheap devices, cheap Internet, and cheaper power (discussed later in this paper). Many governments hope to tap into e-learning to 'leapfrog' skills development. In theory, tablet computers, combined with electricity and a good Internet connection, can give even students in poor, remote schools access to international-standard resources and information, at comparatively low marginal costs.

Dedicated learning resources, such as lesson plans and computer games that provide students with personalized learning challenges (otherwise a struggle for teachers with class sizes of 60 or more), are beginning to emerge, as well as more informal ICT tools such as Google searches, Wikipedia, and YouTube tutorials. Students and teachers can enrol on free online courses such as those provided by edX, Khan Academy, Code Academy (for programming), or Duolingo (for languagelearning), on computers or even smartphones.

One hotly debated programme aims to deliver an entire school curriculum using tablets instead of textbooks. Bridge International provides teachers with just five weeks of training, and then has them teach almost entirely scripted lessons to students. Even fine details, such as hand gestures and the words a teacher should use to praise students on their responses to class questions, are scripted. Bridge says that in its existing schools, students are performing better than those in nonBridge schools in both languages (by 0.34 standard deviations) and mathematics (0.51 standard deviations); a more rigorous study of Bridge is still ongoing. However, this does not signify a 'miracle cure': in a context where primary education spending is a hundredth of that in developed countries, the initial bar is low. Liberia, which suffered 14 years of civil war and then the Ebola crisis, is piloting Bridge's approach in 25 schools to redress a crisis in education; their education minister explained, somewhat apologetically, 'with hundreds of thousands of Liberian children enrolled in failing government schools... now is not the time to be ideological' (Werner 2017).

E-learning has been studied across many contexts. Most studies suggest that computers can improve learning, when used skilfully. In poor schools in India, computer-based maths games were found to improve mathematics ability (by 0.35 to 0.5 standard deviation test score improvements) (Banerjee et al. 2007). In Ecuador, children asked to spend at least three hours per week playing tailored maths and language games improved their maths scores considerably (0.3 standard deviations), with high-achieving students in particular enabled to advance more quickly (Carrillo et al. 2010). A programme in poor rural Chinese schools offered computer-based mathematics games outside of school hours, resulting in modestly improved mathematics scores $(0.12$ standard deviations), with the strongest benefits for poorer students (Lai et al. 2013). Results from 'one laptop per child' programmes in Peru and China find a meaningful increase in students' digital skills (Bet et al. 2014) and mathematical ability (Swinnen et al. 2013). 
These positive impacts are hailed as successes, but improving learning (or perhaps only mathematics learning) by a third of a standard deviation, from an already low base, is not enough to leapfrog sub-Saharan Africa into the services economy. These studies paint a picture of welltargeted ICT bringing helpful, but in the end modest, improvements to human capital development.

Furthermore, some posit that the stewardship of the research teams in the above cases may have heightened the care with which projects were delivered, driving up results artificially. Where teachers are less attentively monitored and supported to integrate computers effectively into teaching, and to repair and maintain devices, and so on, results may be further dampened. There are countless examples of computers collecting dust in storage cupboards because repairs are not budgeted or planned for; computer labs being dominated by a handful of more advanced students; and generally, computers failing to improve learning without the skilled stewardship of quality, well-supported teachers. Many schools in developing countries still lack reliable power, while rural Internet strength and affordability are currently weak.

The full wealth of online information and free international resources can also only be accessed by those fluent in a major world language. Where teachers and students rely on local languages, they cannot tap into these cheap resources, and e-learning is unlikely to seriously bring down costs.

Indeed, many now argue that technology mostly serves to accentuate what is already found in an education system-be that good teaching or bad (Toyoma 2015). A study by Linden (2008) in India found that computer-assisted learning was very effective when used to complement a normal programme, but when it was used as a substitute for a teacher-delivered curriculum, students learned significantly less than they would otherwise have done (-0.57 standard deviations) (Aker et al. 2010).

Others have highlighted that traditional textbooks are in fact very cheap compared with the purchase and maintenance costs of tablet and laptop computers, power, and Internet access. However, as shown elsewhere in this paper, smartphone prices are falling, as well as power and Internet costs. This may well raise the relative cost-effectiveness of e-learning over time. Mobile phones are much cheaper to buy and maintain than computers, and are already much more widespread. In a randomized controlled trial in Niger, Aker et al. (2010) found that a mobile-based adult literacy programme resulted in a 0.3 standard deviation increase in maths scores, and improved writing skills; this is a very similar improvement to that seen from (much more expensive) computer and tablet-based programmes.

Policymakers should thus prepare to embrace the benefits of e-learning, by facilitating initiatives to provide cheap and reliable power and Internet to rural areas, and developing the requisite literacy and language skills in their teachers and students. Even once these foundations are in place, care and skill are required to select the best learning resources from those available, and to effectively work electronic resources into the classroom and broader learning.

\section{ICT to hone marketable skills}

For the lucky few students already equipped with strong literacy, fluency in an international language, reliable power and Internet connections, and confidence in navigating computers and the Internet, there are indications that the Internet is indeed providing unprecedented new learning opportunities. 
Table 1: Using Google Trends to observe interest in online courses

\begin{tabular}{lll}
\hline Interest ranking & \multicolumn{2}{l}{$\begin{array}{l}\text { Countries Googling the term the most in } 2016 \\
\text { (as share of all searches in the country) }\end{array}$} \\
\cline { 2 - 3 } & 'EdX' & 'Online course' \\
\hline 1 & India & Australia \\
2 & Egypt & Ireland \\
3 & Singapore & Pakistan \\
4 & Pakistan & India \\
5 & Peru & Canada \\
6 & Colombia & United Arab Emirates \\
7 & South Africa & South Africa \\
8 & Spain & Nigeria \\
9 & Canada & Bangladesh \\
\hline
\end{tabular}

Source: author's compilation based on data from Google Trends (2017a, 2017b).

Some prestigious international universities are offering free certificated online courses. Carnegie Mellon University has even opened a campus in Rwanda where students can enrol in courses from its US campus (and vice versa for US students), following lectures through videoconferencing. EdX hosts online courses from world-class universities and institutions such as Harvard, Massachusetts Institute of Technology (MIT), and the International Monetary Fund, accessible to anyone with an Internet connection and English fluency. The country for which 'edX' was the most popular search term (as a proportion of all searches in the country) in 2016 was not its home country, the US, but India, followed by Egypt in second place, with South Africa the ninth 'most interested' (the US came in 13th). Using the same measure, five of the top 10 countries Googling 'online course' in 2016 were developing countries (Table 1). There thus seems to be considerable demand for and engagement with tertiary online learning among educated citizens of less developed countries.

However, use of such resources remains mostly an elite activity. Of Nigeria's 170 million population, just 11,500 ( 0.007 per cent) were enrolled with edX in 2013 , while around half of adults are illiterate. In 2015, although the vast majority of Ugandans were subsistence farmers, the top 'how to' Google search in Uganda was not about how to correctly apply fertilizer, when to plant each type of crop, or how to irrigate fields, but 'how to code variables in AMOS'. This highlights the need to broaden education in the fundamentals of literacy, and then fluency in an international language, as well as the need for reliable and cheap power and Internet, if the gains from e-learning are to be more than a drop in the ocean.

One particular opportunity is to become a producer, rather than simply a consumer, of digital content. Learning to program, for example, does not require a college degree or even completion of secondary school. Free online platforms such as Code Academy can take people from zero to a marketable level of skill, and even children can learn to code to an advanced level with free platforms such as Scratch. Dedicated coding boot camps are starting in many African countries. Coding boot camps in the US have developed innovative financing models that may also help to remove barriers to entry in Africa: schools cover students' costs upfront, recovering them by taking a percentage of salary upon graduation.

Scratch is a promising example of efforts to broaden opportunities to learn to code. It is a free online (and downloadable) programme designed by MIT researchers to teach coding to young people and teens. Scratch code is 'written' using easy and colourful drag-and-drop boxes and lists of commands to select. Despite this superficial simplicity, Scratch users can work up to complex and highly engaging creations-from animations, to interactive games, stories, and art (including 
projects that integrate webcam sensors), to polls, moving birthday cards, and more. Users can also collaborate on projects, comment on one another's work, look at the underlying code of projects they like to understand how they were made, and so on. Several programmes teaching coding to children begin with Scratch to teach coding basics, before graduating to more standard suites such as HTML and Python. Despite only having been launched in 2005, Scratch now has 11 million unique visitors per month, and is growing rapidly, with almost half a million new visitors per month. The modal age of its users is just 12 years old. And its reach in developing countries is growing: in April 2017, there were more than 5,600 Scratch users in Kenya, 2,700 in Somalia, and 35,000 in South Africa (Scratch 2017). Scratch is being used by several coding education programmes in Africa, such as Code Club Kenya and Africa Code Week.

To try to overcome the barriers to coding faced by less privileged students, Africa Code Week facilitates governments and non-governmental organizations (NGOs) to run workshops across Africa, from cities to small villages, to introduce children to coding (often using Scratch). Despite being only the second ever Africa Code Week, 2016's event had over 450,000 participants in 30 countries (Batambuze 2016). Events like this can help to inspire children's interest in code. However, the same core literacy skills emerge as crucial to ensuring that children can really pursue learning after such events.

How might Africa's future coders be employed? One strong contender is mobile app development. GSMA (2015) predicts that by 2020, the number of smartphones in sub-Saharan Africa will have more than trebled, from 160 million in 2015 to 540 million. These new smartphones will overwhelmingly be in the hands of young people, and a tendency is already emerging for young people in developing countries to innovate apps to meet their particular needs. UNESCO YouthMobile (UNESCO 2016) supports organizations teaching mobile app development to lowincome people in developing countries, and highlights that young people in developing countries have already created apps to:

- provide pregnant women with information on caring for their babies, storing their medical records, and improving communication with doctors in an emergency (Senegal);

- connect farmers with industry buyers to improve farmer profits (Rwanda);

- provide farmers with information on how to support their crops (South Sudan);

- track real-time traffic conditions to reduce congestion (Cambodia);

- provide learning materials to primary school students (Senegal); and

- inform young people about scholarship opportunities (Cambodia).

To summarize the potential of e-learning for sub-Saharan Africa, most apparent is the divide in the educational opportunities offered by new technologies. For jobseekers in sub-Saharan Africa with computer literacy and fluency in a major international language (especially English), the expansion of regular, reliable, affordable Internet access and power offers an incredible opportunity to learn new marketable information and skills, gain superior qualifications, interact and collaborate with people from all over the world, and even sell their services online.

People without strength and confidence in these core skills, especially literacy, and lacking affordable power and Internet, will struggle to benefit from the educational opportunities of the digital revolution. Thus to advance education through ICT, or build an ICT- (or knowledge-)led economy, educational resources should be channelled to cement broad-based and strong literacy, and fluency in a major world language, as the foundations for effective engagement with digital content and the opportunities it offers. 


\subsection{Reducing labour costs}

\section{Searching for Africa's green revolution}

In Asia, over the course of the 1960s and 1970s, improved varieties of wheat and rice spread rapidly, alongside investments in irrigation and increased use of fertilizer and pesticides. This helped yields to double and production to triple between the 1960s and 1990s, while agricultural productivity remained fairly stagnant in Africa (FAO n.d.).

As the supply of food increased and prices fell in Asia, rural labourers moved to the cities to take advantage of new opportunities, especially in the manufacturing sector. In Africa, urbanization is occurring later, and in an environment of fairly stagnant rural productivity growth (Table 2) coincident with a rapidly expanding working-age population. Many young people move to the city knowing the countryside cannot sustain them; whether or not they will find a job is a gamble they are forced to make, and food and other urban living costs remain high. Workers tend to be employed in low-productivity jobs such as corner shop work or day labour on low-tech construction sites.

Table 2: Agricultural productivity growth $2001-2013$ by region

\begin{tabular}{lccc}
\hline Region & Annual percentage growth, 2001-2013 \\
& Agricultural output & All inputs & Total factor productivity \\
& & & \\
\hline Asia (except West Asia) & 3.43 & 0.81 & 2.62 \\
Latin America & 3.12 & 0.98 & 2.14 \\
West Asia and North Africa & 2.48 & 0.39 & 2.1 \\
Developing countries & 3.36 & 1.41 & 1.96 \\
Developed countries & 0.55 & -1.37 & 1.92 \\
North America & 1.05 & -0.75 & 1.8 \\
Transition economies & 1.76 & 0.03 & 1.73 \\
World & 2.52 & 0.81 & 1.7 \\
Europe & -0.07 & -1.58 & 1.51 \\
Sub-Saharan Africa & 3.24 & 2.66 & 0.58 \\
\hline
\end{tabular}

Source: author's compilation based on data from USDA ERS (2017).

Pressures on food costs are becoming even more intense as climate change reduces the suitability of environments for food production, and as the global population rises towards nine billion.

One technology that may be important in addressing this challenge is the genetic modification (GM) of crops. Genetic engineering is the direct editing of the genome of a plant. DNA responsible for desired traits, such as pest or drought resistance, or improved nutrient content, is copied from other species and artificially inserted into the genome of the target plant. By introducing the right genes, genetic modification can boost crops' resilience to climatic changes, diseases, and pests, and boost crops' nutritional content. 
Agriculturalists can also achieve many of these gains through selective breeding. However, this is a slow process, requiring several generations of plant breeding before the desired characteristic manifests itself with the required strength. Perhaps more importantly, the process of selective breeding for one trait can unintentionally breed out other desirable genes. For example, the selective breeding of drought-resistant maize has floundered due to the low initial genetic variation of maize crops and resultant loss of desirable traits during the selective breeding process. Finally, selective breeding only allows the addition of genes from sexually compatible organisms (e.g., maize bred with maize), whereas GM allows genes to be added from sexually incompatible organisms (e.g., a maize gene to a cotton plant), unlocking a wider range of possible traits.

For example, Cry proteins from the bacterium Bacillus thuringiensis $(\mathrm{Bt})$ have been bioengineered into corn and cotton genomes, giving the plants a Bt toxin that acts as an insecticide to the bollworm pest. By 2014, this cotton had been planted by 7.7 million farmers in India, and 7.1 million in China (ISAAA 2014). Not only does it reduce crops' susceptibility to bollworm, it also reduces the need for expenditure on insecticides. Furthermore, while traditional insecticides destroy a wide range of animals, the Bt toxin is targeted towards a specific pest only, helping to protect non-invasive wildlife.

In 2016, a particularly severe El Niño drought caused food insecurity in many Southern African countries, which particularly affected maize. The maize harvest of Malawi-a country heavily dependent on maize-fell 34 per cent below its five-year average, and about 20 per cent of the population faced food insecurity (GIEWS 2017). One promising GM field trial is testing droughtresistant maize with pest control (Bt) for several African countries. This is spearheaded by the Water Efficient Maize for Africa project, which hopes to launch the first crop in South Africa in 2017.

Potatoes are the world's third most popular food crop, but are at risk of late blight (the disease responsible for the Great Irish Famine of the 1840s, which reduced Ireland's potato harvest by 88 per cent, causing over a million to starve to death and a further two million to emigrate). Late blight spreads rapidly in warm and moist conditions, which are common in many parts of subSaharan Africa today, and although fungicide and metal spraying can reduce risks, these are practised by relatively few subsistence farmers in Africa (Sengooba and Hakiza n.d.). GM potatoes resistant to late blight have enjoyed positive field trials in Bangladesh, and are starting to be trialled in Uganda. The genetic modification allows several resistant genes to be introduced into the same potato variety, to optimize resistance in a way not feasible with selective breeding.

GM crops may also reduce malnutrition in sub-Saharan Africa, now a bigger problem than hunger in many countries. Worldwide, 250 million people are Vitamin A deficient, to which UNICEF attributes one to two million preventable deaths per year (UNICEF 2016). 'Golden Rice' is genetically engineered to contain beta-carotene, a source of Vitamin A found naturally in foods such as squash, carrots, and papaya. Rice is the most consumed food product in the world, and the Vitamin A in Golden Rice is bioavailable. Although the product has been under development since the 1990s, Golden Rice varieties so far have failed to consistently provide the yields of nonGM rice, a factor believed to be holding back the technology's commercial release (Stone and Glover 2017). However, proponents of Golden Rice say that unhelpful regulatory barriers have also contributed to this slow development.

Globally, a record 181 million hectares of GM crops were planted across 28 countries in 2014. The US, historically more open than most regions to GM crops, represents 73 million hectares of this total, with over 90 per cent of its maize, soybean, and cotton now genetically modified. Brazil, Argentina, India, and Canada are also large planters of GM crops (ISAAA 2014). In June 2016, 121 Nobel laureates signed a letter of support for GM crops, asking activists to stop impeding 
their take-up. They stated: 'There has never been a single confirmed case of a negative health outcome for humans or animals from their consumption. Their environmental impacts have been shown repeatedly to be less damaging to the environment, and a boon to global biodiversity' (Support Precision Agriculture 2016).

But GM crops are heavily regulated in sub-Saharan Africa-much more so than selectively bred crops-with considerable fear and scepticism about their potential. This may reflect Africa's closer ties to Europe (through aid and colonialism), which is typically highly sceptical of GM. The EU plants less than 150,000 hectares of GM crops, 132,000 of which are in Spain (Bt cotton), and African governments and NGOs have often questioned why they should adopt these technologies about which Europeans are so sceptical.

By 2014, only two countries in sub-Saharan Africa had approved GM crops for commercial use: South Africa (2.7 million hectares of maize, cotton, or soybean) and Burkina Faso (0.5 million hectares of cotton). South Africa has been by far the most open country, with legislation and testing procedures in place to facilitate development and commercial planting. It is the only country in sub-Saharan Africa to allow GM staple food crops (such as Bt maize). Other countries wishing to benefit from GM technology may learn from South Africa's research, marketing, and risk management practices for GM crops. Six further countries were beginning field trials: Cameroon, Nigeria, Ghana, Malawi, Uganda, and Kenya (ISAAA 2014). In other countries, there is little to no movement towards the development of GM crops. National biodiversity councils must grant approval for any open field trials to begin, and then must approve crops for commercial sale once trials are completed and evidence submitted. This approvals procedure, although appropriate in theory, is reportedly highly inefficient in many countries.

Genetically modified crops do bring risks than must be managed. For example, the toxins bred into GM Bt cotton target certain pests, giving the plants a natural insecticide against them. But because the GM cottonseeds were so popular in China and India, not enough 'refuge areas' (without the Bt cotton) were left for the targeted pests, leading these to develop resistance to the toxins. Policymakers in the US avoid this, however, by demanding that farmers leave 20-50 per cent of land Bt-free within $0.8 \mathrm{~km}$ of their Bt plantations, so pests need not develop resistance.

Strains developed must also be thoroughly tested to ensure adequate resistance to other pests. For example, the strain of cotton into which the Bt toxin was engineered in India has retrospectively proven susceptible to whitefly, whereas local organic varieties are not (Indian Express News Service 2015). Mirid bugs similarly blighted GM cotton yields in northern China (European Commission DG Environment News Alert Service 2010). These losses might have been avoided with proper field trials before commercial release of the crop. On the other hand, these risks also result from the tiny range of GM and hybrid strains available on the market, a challenge sometimes exacerbated by slow regulatory processes.

There is no evidence, or reason to believe, that such risks are higher than or different from the risks of selectively bred crops. For both, policymakers must invest in modernizing the approval process to ensure varieties are tested thoroughly but also efficiently, so that more and better varieties become available to farmers. They must also regulate the use of crops, pesticides, and insecticides appropriately, and work to improve communication about GM crops to the public, so that problems with specific varieties do not incorrectly damage the image of GM as a technology in general.

Genetic modification is by no means the only source of agricultural productivity gains. So far, selective breeding has produced far more new crop varieties for sub-Saharan Africa than genetic modification, and increasing investments in agriculture research for selective breeding are still 
predicted to have large returns (Perez and Rosengrant 2015). The particular promise of GM derives partly from its greater speed and flexibility compared with selective breeding, but also from the fact that the development of GM varieties has so far been so restricted. With more favourable legislation, and modernized testing and regulatory processes, Africa could enjoy a rapid growth in GM crop development, and in the quality and range of varieties available to farmers. Over less than a decade, this could make a huge difference to the reliability of food supplies, the affordability of food, the nutrition and health of populations, wage competitiveness, and opportunities for food export growth.

\section{Overcoming shortfalls in local skills}

Manufacturing sectors in much of sub-Saharan Africa lack sophistication and diversity, and skills for upgraded processes are often hard to find in the local labour market. This can be a challenge even for the manufacture of simple products: which local engineer can fix the machine? How can niche or complex parts for machinery be replaced in time? How can new ideas be prototyped and tested? On top of this, supply chains for parts tend to be weak, due to expensive and slow overland travel, small and unsophisticated local markets, and poor logistics sectors. This raises the risk that if one part of a machine breaks, a business may need to halt operations for days or weeks while the requisite part or technical expertise to fix the machine are sourced.

3D printing, or 'additive manufacturing', is the process of building 3D objects by adding ('printing') layer upon layer of material. The product to be printed is designed in 3D printing software, which then feeds the design into the 'printer'. The machine has one or many controlled nozzles, which generally emit the material in liquid form, for it to then set. In other cases, the material is emitted as a powder, fused using lasers. The material is thus laid down, starting with the bottom crosssection of the object and gradually 'printing' successively higher layers. Plastic is the most common material 'printed', but any material with an appropriate melting point can in theory be printed.

Because of the fine control of the nozzle and the additive nature of manufacturing (which avoids 'joins', which can weaken a structure), 3D printing allows an almost unlimited range of shapes to be created with ease. This has led many manufacturing firms to use 3D printers for prototyping parts and products. 3D printing can also be used for personalized parts: the medical profession is already using $3 \mathrm{D}$ printing for dental crowns, and scientists have printed bone, muscle, and cartilage, as well as a titanium ribcage that was implanted into a person in Spain. 3D printing is also useful for very niche products, such as parts for customized or rare machinery where building a mould and establishing a typical supply chain is not cost-effective due to low volumes.

$3 \mathrm{D}$ printing is a promising prospect for manufacturers in less developed countries. When a niche or complex part of their machinery needs to be replaced or fixed, rather than waiting weeks for an expensive shipment or rare expert, firms may be able to simply 'print' a new part. Firms can use their own machines, or share machines at (for example) city-level 3D printing labs, to have parts almost instantly ready for use. Thus firms in sub-Saharan Africa can more confidently rely on sophisticated machinery and processes, knowing that new parts can be quickly found and created, in spite of weak engineering skills and traditional supply chains.

3D printing can also be an export opportunity for sub-Saharan Africa. Africa's talented entrepreneurs can create designs to be exported (printed) around the world, as a form of online service export. Already, Kodjo Afate Gnikou, an entrepreneur who scavenged electronic waste to create batteries and 3D printers in Togo, is now supporting the Made in Space programme to design 3D printers for space (Hall 2016). 
One creative application is the use of 3D printing to address the high cost of housing in Africa. 3D printing offers many benefits for house production, including speed, the need for fewer labourers, a chance to overcome weak local architectural skills, and the opportunity to use costsaving shapes and materials. A Chinese firm, Win Sun, claimed to have 'printed' ten concrete houses in 24 hours, at US\$5,000 per house, in 2015. The World Advanced Saving Project is working on another 3D printer-the Big Delta $12 \mathrm{~m}$ - that prints locally available materials, such as soil mixed with seeds, which can include features such as cavity walls (tricky with traditional building techniques) as well as coverings to improve look and durability. Its inputs are almost free, and it aims for the final printer to be able to operate with solar power for off-grid areas.

Additive manufacturing may thus improve the efficiency of production in Africa by making it easier for firms to access niche inputs (especially for machinery) and prototype their ideas, providing new export opportunities and reducing wages.

\section{$4 \quad$ Power}

\subsection{Cheaper, less carbon-intensive generation}

In 2010, average generation costs were US $\$ 0.18$ per $\mathrm{kWh}$, leading to subsidized energy tariffs of on average US $\$ 0.14$ per kWh. By comparison, average tariffs in South Asia were US $\$ 0.04$ per kWh, and in East Asia US\$0.07 per kWh (AfDB 2013). The use and production of power in Africa is similarly low: just $147 \mathrm{GW}$ was produced in 2013, equivalent to the capacity installed in Belgium, and the new capacity installed in China every one to two years (AfDB 2013). To compound high prices, many African countries suffer frequent power outages, necessitating firms to use expensive backup diesel generators. This makes it particularly tough for (typically energy-intensive) manufacturing sectors in sub-Saharan Africa to compete with those in Asia.

However, much of the continent is also rich in sources of renewable energy: solar, hydro, wind, and even geothermal in East Africa. Thanks to ongoing research to hone techniques, the costs of solar and wind have been falling rapidly, so that renewables already supplied nearly a quarter (23.7 per cent) of global power in 2015 (REN21 2016). Despite the plummeting cost of oil (67 per cent), wind and solar accounted for half of new global investment in power generation in 2015 (Frankfurt School-UNEP Collaborating Centre 2016).

Furthermore, with less 'legacy infrastructure' in their power generation, sub-Saharan African countries are well placed to transition straight to renewables as their energy demand grows. Developing countries are constructing more renewable energy capacity than their OECD counterparts (REN21 207), and China's renewable energy capacity is now growing faster than its fossil fuel and nuclear capacity (Mathews and Tan 2014). If sub-Saharan Africa can indeed leapfrog past fossil fuels and directly to cost-effective renewables, it can avoid the massive exacerbation of climate change that would result from meeting future demand through coal power, and bring prices down at the same time.

\section{Hydroelectricity}

In 2012, hydropower was the source of three quarters of global renewable energy production and 84 per cent of Africa's non-fossil fuel energy (SciDev n.d.). Africa's hydro projects are not particularly benefiting from new technologies. However, they provide important context for considering the impact of improved solar and wind technologies. 
Despite the high share of hydropower generation, by 2016 Africa had exploited just eight per cent of its total hydropower potential (IRENA 2015). Huge expansion projects are already underway or planned. For example, Ethiopia is planning to complete a $6 \mathrm{GW}$ hydropower dam on the Nile (the Grand Ethiopian Renaissance Dam) in 2017, which would triple Ethiopia's energy generation from $2 \mathrm{GW}$ in 2016. Three quarters of Ethiopians currently lack access to power, and the project could not only relieve much of this energy poverty, but also provide cheaper energy to export to the Horn of Africa and East Africa. Across Africa, the total power that would be created by all planned hydro projects is $27 \mathrm{GW}$, with even Ethiopia planning to complete two further hydro plants of above $1 \mathrm{GW}$ by 2020 .

However, hydropower comes with serious drawbacks, as many African countries reliant on hydro are now witnessing. As well as disrupting rivers-and thus habitats for wildlife, and water for settlements and crops-hydro is particularly unreliable in the context of climate change. Zambia, for example, gets nearly all its power from hydroelectricity, 90 per cent of which comes from three dams. In fact, it is home to the world's largest artificial reservoir (the Kariba Dam)—the biggest source of power not only for Zambia, but also for neighbouring Zimbabwe. But with severe droughts in the region in 2015, Zambia suffered daily eight-hour power cuts and a total shortfall of 34 per cent of demanded electricity. Even the mining industry, core of the Zambian economy, had to cut power usage by 30 per cent (Sladoje 2016).

The serious shortfalls of hydropower highlight the need to diversify sources of power. Fossil fuels are, of course, one option, but as well as being polluting, their fluctuating prices are harmful to planners and consumers. Other renewables, especially solar and wind, have enjoyed rapid cost reductions, making them now competitive with fossil fuels from a pure cost perspective in many contexts. In 2016, Zambia ran a tender for $100 \mathrm{MW}$ of solar power to stabilize its power supply; the winning bids offered US\$0.06 and US $\$ 0.08$ per $\mathrm{kWh}$ - competitive with South and East Asian prices (IFC 2016).

Solar

Global solar capacity was $222 \mathrm{GW}$ in 2015 , but despite its favourable climatic conditions, just 2.2 GW of this were installed in Africa (IRENA 2016). This suggests huge potential for future investment.

Three key 'technical' factors drive the cost of solar power: the cost of installing the required capacity, the costs of transmitting the energy from source to user, and the percentage of the installed capacity that is actually generated ('capacity factor').

The costs of installing solar capacity have been falling rapidly with refinements to the technology. Costs fall by approximately 20 per cent with each doubling of capacity, a fall faster than any other power generation technology. Thus costs per watt installed have fallen by more than 99 per cent since 1976, and by 90 per cent since 2009 alone. New solar projects can now provide energy at or below the average grid price in 30 countries (World Economic Forum 2016), and in South Africa newly installed solar and wind are 40 per cent cheaper than baseload coal (CSIR 2016). For this reason, as costs continue to fall, sub-Saharan African countries-generally abundant in sunlight (irradiation)_-are looking increasingly to solar as a reliable and affordable power source.

Africa's particular advantage for solar, of course, comes from its high capacity factor. The capacity factor compares the energy that would be produced were a source active at full capacity, 24 hours a day and 365 days a year, with the actual (lower) generation that results from (in the case of solar) the night and other periods of low-intensity sun. Due to the prolonged and more intense 
irradiation, a solar plant in Africa will tend to produce almost double the power of a similar-sized plant in Germany, making the technology more promising (IRENA 2016).

The inability of solar photovoltaics to generate power during darkness, however, is a major drawback compared to hydro or fossil fuel plants. This weakness could be reduced by power storage, costs of which have finally begun to fall meaningfully. The average price of battery packs in 2010 was US $\$ 1,000$ per $\mathrm{kWh}$, but by 2015 this had fallen to just US $\$ 350$ per $\mathrm{kWh}$. A 2016 UNEP report (Frankfurt School-UNEP Collaborating Centre 2016) attributes this drop to the intense battery innovation and production economies of scale driven by the electric vehicle movement. Utility-scale electricity storage increased by 50 per cent in just a year, from $160 \mathrm{MW}$ in 2014 to 250 MW by 2015. Furthermore, a massive new solar plant in the Moroccan desert employs a novel power storage mechanism to provide power after dark: its solar 'mirrors' heat an oil solution ('heat transfer solution'), which then heats molten salts that retain their temperature for up to eight hours. When the power is required, the liquid is simply mixed with water to create steam that turns turbines. The technology is more expensive than solar photovoltaics, but offers $24 / 7$ power for countries with adequate irradiation (Nelson 2015).

The costs of transmitting energy from source to user remain a challenge for solar power proliferation in Africa. Grids are not yet extended to many areas that might house either solar plants or consumers. Furthermore, many stretches of existing grids were not built to handle twodirectional power, and thus require expensive upgrades in order to transmit power from new solar plants. Improved power storage would ease this constraint, but is also currently expensive.

Innovations in business models for solar power have been almost as impressive as innovations in the technology itself, however. Solar home systems and mini-grids particularly aim to work around these transmission challenges. However, in return for reduced transmission costs, local solar generation in Africa often suffers poor economies of scale. Due to lower household incomes and firm sizes, solar home systems in Africa are typically 20-100 W, compared with 3,000-5,000 W (3-5 kW) in OECD countries. As a result, costs per installed watt are US $\$ 4-16$, compared with typical costs of US\$2.5-7 per watt for systems over one kilowatt (IRENA 2015). However, there is no barrier to larger firms installing larger, more cost-efficient systems to power off-grid production.

Despite their drawbacks, solar home systems are nonetheless transformative for many families. Their power is often cheaper than the alternative kerosene lighting, despite offering better-quality light - around 400 lumens compared with up to 40 for a kerosene lamp-and avoiding the air pollution and resultant morbidity associated with kerosene. Solar power is also used to charge mobile phones and is often offered for a fee by small businesses, which can beat diesel-powered generators by averting transport costs and through the zero marginal cost of power to the provider. Solar home systems can even offer cheaper and/or more reliable power than connecting to proximate grids (IRENA 2016).

\section{Wind}

Although the falling costs of solar have made more headlines, the costs of wind power have also fallen exponentially since 1985, when wind power in northern Europe cost on average US $\$ 512$ per MWh. In 2016, that cost was US\$70, reflecting a 50 per cent reduction since 2009 alone (Liebreich 2016). This drop in costs has mostly resulted from enhanced designs improving the capacity factor of new wind turbines. The capacity factor of OECD wind turbines installed in the 1990s and early 2000s was generally between 10 and 20 per cent, but average rates for those installed in 2016 were 
above 30 per cent (Liebreich 2016). Capacity improvements are resulting from refined blade shapes and higher towers, among other design innovations.

The Horn of Africa, south-west coast, and parts of north-west Africa have strong wind capacity (Vaisala 2015), and African governments are planning serious investments. Kenya's ongoing Lake Turkana wind farm is planned to provide $310 \mathrm{MW}$ to Kenya's national grid-equivalent to 18 per cent of total energy demand in 2016. If completed, it will be the largest wind farm in Africa, and the largest private investment in Kenya's history (Obulutsa 2017).

\subsection{Energy/carbon-saving appliances}

Technology is not only improving energy generation-it is also helping to reduce the energy needs of firms and consumers. A prime example is in the transport sector. African countries are adopting global ride-sharing apps such as Uber, and domestic versions for shared motorcycle taxis (e.g., SafeBoda in Uganda and SafeMotos in Rwanda). In 2016, Volkswagen announced their plan to introduce electric cars with a ride-sharing service in Rwanda, to take advantage of cheap renewable grid power. Companies such as Ampersand Solar are also hoping to bring China's electric bike revolution to Africa (there are over 200 million electric bikes in China-one for every seventh person in the country), replacing the omnipresent motorbike taxis with solar-powered electric bicycles. Sub-Saharan Africa can benefit from leapfrogging straight to the optimal technology in the case of appliances as well as generation, because many consumer habits, and much energy infrastructure, have yet to be formed.

Thus, although in Africa energy costs have been a serious burden to manufacturing industries and households, and a disincentive to investors, the future for affordable energy in Africa looks much brighter. The falling costs of solar and wind power will make generation more affordable and reliable (and less carbon-intensive), while appliance innovations can reduce the energy- or carbonintensity of economic and population growth, to multiply any positive effects.

\section{Conclusions}

There is considerable scope for sub-Saharan Africa to enjoy leapfrog growth thanks to recent and forthcoming technologies. This paper has considered illustrative examples: e-commerce can improve firms' access to inputs and consumers; the Internet offers opportunities for exceptional skills development; unleashing agricultural technologies such as GM crops might release burdens on food prices that keep wages high and nutrition low; and solar and wind technologies can bring down the cost of power substantially.

However, for these and other technology-driven growth opportunities to deliver on their potential, certain fundamentals need to be in place.

There are serious barriers to e-commerce taking off in Africa-want of a common language, expensive transport routes, poor integration of payment and banking systems, weak postal and courier services, and some of the world's highest data costs and lowest levels smartphone ownership, to name a few. Yet despite these barriers, e-commerce is already enjoying considerable demand, with online marketplaces and banks some of the most visited websites in many subSaharan African countries, and tens of millions of dollars invested in lead e-commerce firms. This suggests a strong latent demand for e-commerce, to overcome limited product offerings and high costs domestically. 
But e-commerce has not been used intensively for exports from Africa. To facilitate this transition, governments will need to prioritize the fundamentals of trade: is the 'boring' infrastructure in place to efficiently transport goods from A to B-roads, ports, efficient borders and customs, railways, waterways, and so on? Can national postal services deliver parcels in a timely and reliable fashion? Are the standards for goods and services harmonized, and simplified, across countries, so that these can indeed be traded?

Certain e-commerce-specific policies are also required. First, governments and the private sector should ensure that data costs continue to fall, taking advantage of the oversupply of satellites over Africa as well as other new Internet infrastructure. Second, it will be vital to shepherd mobile money providers, e-payment platforms, and banks to ensure interoperability across platforms and countries, or the vast majority of potential trades and transfers will be foregone due to too-high transaction costs. Third, firms should innovate to organize and integrate logistics services, to deliver fast, reliable, and affordable goods transport.

Thanks to current transport and logistics inefficiencies, the service sector has been growing faster than manufacturing in most sub-Saharan countries. Many national strategies in turn identify services as the intended driver of future growth. But as Dani Rodrik (2016) has warned, recent service-sector growth has mostly constituted inefficient domestic 'street corner' services, which cannot drive economic growth indefinitely. Resilient service-led growth demands strong human capital, whereas education quality has been a pervasive problem in sub-Saharan Africa.

Internet access can be transformative for human capital development for those with a strong foundation of literacy, fluency in an international language, and critical-thinking and independentstudy skills. With affordable and quality data and cheap devices, people can learn independently from an almost limitless pool of information, and take advantage of the world-class free resources available online. Without a high level of literacy, by contrast, most content on the Internet can be neither found nor understood, and computers in classrooms serve a role more similar to textbooks and taught lessons. The impacts of ICT on learning in otherwise under-resourced schools have been studied rigorously and found to be generally positive, but decidedly modest. Thus literacy, and fluency in a major international language, must be prioritized for citizens to reap the gains of e-learning, followed by broad, affordable, reliable data.

Labour has been less competitive in sub-Saharan Africa not only due to low skills, but also due to high living costs driving up wages, even for unskilled work. Whereas Asia benefited from the green revolution, which multiplied agricultural production threefold in 30 years, agricultural growth in Africa has been sluggish. There has been underinvestment in seed development through selective breeding, and unlike in Asia and Latin America, most African countries have expressed a particularly strong reaction against genetic modification. This fear of GM may be inherited from Europe-a major influence on many sub-Saharan African former colonies- where, unlike in the US, governments have mostly resisted the planting of GM crops. The (substantial) available evidence finds no greater risk from GM crops than selectively bred crops. For both, the key to success is quite standard risk management, such as thorough field trials and enforced 'refuge areas' for pest-resistant crops. At the same time, governments should work to improve investment in and efficiency of testing and approval processes, so that more varieties become available to farmers more quickly. GM and selectively bred crops have the potential to multiply yields, be more resilient to climate change, and boost the nutritional content of food. With the pressures on food prices, food security, and nutrition facing so many sub-Saharan African countries-which will likely become even greater with climate change and population growth-research into GM and selective breeding should be embraced. 
The high cost of power has rivalled labour productivity as a deterrent to investment and business expansion in sub-Saharan Africa. Average tariffs in Africa are more than double those in Asia, in spite of subsidies. So far, hydropower has been the dominant source of renewable energy, but this source is not reliable, especially in the face of droughts exacerbated by climate change. Again, technological advances offer serious promise to leapfrog sub-Saharan Africa to the efficiency of competing regions. Solar is already competitive with existing grid power in 30 countries, and costs are falling by approximately 20 per cent per year. With its superior irradiation and lack of legacy infrastructure', solar's potential in Africa is particularly strong; in South Africa, for example, new solar and wind are 40 per cent cheaper than baseload coal. The costs of power storage are also finally starting to fall, so solar can begin to supply grids and homes in the night. Albeit less dramatically, wind power costs are also falling, and can compete with fossil fuels in several African countries. Solar and wind are thus likely to play a serious role in Africa's energy future. Governments can prepare to take advantage of these cheap power opportunities by upgrading grids where necessary, anticipating low energy costs when negotiating tariffs and planning infrastructure (as seen, for example, in East Africa's pursuit of electric vehicles), and embracing solar mini-grids and home systems as positive if interim solutions. If price reductions continue on trend, and if governments prepare appropriately, these changes could bring Africa's power costs to internationally competitive levels.

The impact of new technologies on economic development in sub-Saharan Africa will depend on how far governments create enabling environments for them through investments in more 'boring' fundamentals such as infrastructure, literacy, and sound regulatory institutions. Rather than offering a shortcut past these foundations, technology builds on them, providing a potentially powerful multiplier for development to proceed at an accelerated pace. As wages rise rapidly in Asia, this paper has highlighted the case for optimism that with these foundations in place, subSaharan Africa can indeed benefit from new technologies to become globally competitive in a much wider range of manufacturing as well as productive agricultural and service sectors.

\section{References}

AfDB (2013). 'The High Cost of Electricity Generation in Africa'. Available at: www.afdb.org/en/blogs/afdb-championing-inclusive-growth-across-africa/post/the-highcost-of-electricity-generation-in-africa-11496/ (accessed 11 May 2017).

Aker, J., C. Ksoll, and T. Lybbert (2010). 'ABC, 123: The Impact of a Mobile Phone Literacy Program on Educational Outcomes'. SSRN. Available at: papers.ssrn.com/sol3/papers.cfm?abstract_id=1694142 (accessed 11 May 2017).

Alexa (2017). 'Top Sites in Kenya'. Available at: www.alexa.com/topsites/countries/KE (accessed 11 April 2017.)

Babej, M.E. (2014). 'How Jumia is Adapting E-Retail to Africa'. Forbes, 16 June. Available at: www.forbes.com/sites/marcbabej/2014/06/16/how-jumia-is-adapting-e-retail-toafrica/\#5e5703d311e9 (accessed 11 May 2017).

Banerjee, A., S. Cole, E. Duflo, and L. Leigh (2007). 'Remedying Education: Evidence from Two Randomized Experiments in India'. Quarterly Journal of Economics, 122(3): 1235-64.

Batambuze, E. (2016). 'Africa Code Week Exceeds Targets and Trains 427,000 Students in One Week'. PC Tech Magazine, 24 November. Available at: pctechmag.com/2016/11/africa-codeweek-exceeds-targets-and-trains-427000-students-in-one-week/ (accessed 11 May 2017). 
Bet, G., J. Cristia, and P. Ibarraran (2014). 'The Effects of Shared Technology Access on Students' Digital Skills in Peru'. Washington, DC: Inter-American Development Bank.

British Council (2014). 'Can Higher Education Solve Africa’s Job Crisis?’ London: British Council.

Broadband Commission for Sustainable Development (2016). 'State of Broadband Report'. Geneva: Broadband Commission for Sustainable Development.

Cainiao Network (2016). 'Logistics in China: Scale and Uniqueness'. Available at: www.alibabagroup.com/en/ir/pdf/160614/11.pdf (accessed 13 May 2017).

Carrillo, P.E., M. Onofa, and J. Ponce (2010). 'Information Technology and Student Achievement: Evidence from a Randomized Experiment in Ecuador'. SSRN. Available at: papers.ssrn.com/sol3/papers.cfm?abstract_id=1818756 (accessed 11 May 2017).

Central Bank of Kenya (2017). 'Mobile payments'. Available at: www.centralbank.go.ke/nationalpayments-system/mobile-payments/?yr=2015 (accessed 12 April 2017).

Chen, L. (2014). 'Alibaba's IPO by the Numbers'. Forbes, 19 September. Available at: www.forbes.com/sites/liyanchen/2014/09/19/alibabas-ipo-by-the-numbers-bigger-thangoogle-facebook-and-twitter-combined/\#7a20ebae7c2e (accessed 11 May 2017).

CSIR (2016). 'Cost of New Power Generation in South Africa'. Pretoria: CSIR.

The Economist (2013a). 'Daily Chart'. The Economist, 7 October. Available at: www.economist.com/blogs/graphicdetail/2013/10/daily-chart-5 (accessed 11 May 2017).

The Economist (2013b). 'E-commerce in China: The Alibaba Phenomenon'. The Economist, 23 March. Available at: www.economist.com/news/leaders/21573981-chinas-e-commercegiant-could-generate-enormous-wealthprovided-countrys-rulers-leave-it (accessed 11 May 2017).

The Economist (2017). 'The Lure of Speed: Railways'. The Economist, 14 January.

European Commission DG Environment News Alert Service (2010). 'GM Cotton Increases Mirid Bug Outbreaks in China'. Bristol: European Commission.

FAO (n.d.). 'Towards a New Green Revolution'. Rome: FAO. Available at: www.fao.org/docrep/x0262e/x0262e06.htm (accessed 11 May 2017).

Frankfurt School-UNEP Collaborating Centre (2016). 'Global Trends in Renewable Energy Investment'. Frankfurt: FS-UNEP.

Frazer, G. (2016). 'The Boring Infrastructure that Rwanda Needs'. Available at: www.theigc.org/blog/the-boring-infrastructure-that-rwanda-needs/ (accessed 11 May 2017).

Frischtak, C.R. (2017). 'Industries without smokestacks: Telecommunication and ICT-Based Services Trade’. WIDER Working Paper 2017/6. Helsinki: UNU-WIDER.

GIEWS (2017). 'Country Brief: Malawi'. Available at: www.fao.org/giews/countrybrief/country.jsp?code=MWI (accessed 11 May 2017).

Google Trends (2017a). 'Google Trends: Edx'. Available at: trends.google.com/trends/explore?date=allandq\%3Dedx (accessed 14 April 2017).

Google Trends (2017b). 'Google Trends: Online Course'. Available at: www.google.com/trends/explore?date $=$ all\&q $=$ online $\% 20$ course (accessed 14 April 2017).

GSMA (2015). ‘The Mobile Economy: Sub-Saharan Africa 2015’. London: GSMA.

GSMA (2016). 'Driving a Price Revolution: Mobile Money in International Remittances'. London: GSMA. 
GSMA Intelligence (2016). 'The Mobile Economy Africa 2016’. London: GSMA.

Hall, N. (2016). 'Why 3D Printing Matters in Africa'. Available at: 3dprintingindustry.com/news/3d-printing-matters-africa-80862/ (accessed 11 May 2017).

IFC (2016). 'IFC Strategy 3.0’. Washington, DC: World Bank Group.

ILO (2016). 'Global Wage Report 2016/17’. Geneva: International Labour Organization.

Indian Express News Service (2015). 'Whitefly Lessons'. The Indian Express, 23 October. Available at: indianexpress.com/article/opinion/editorials/whitefly-lessons/ (accessed 11 May 2017).

International Telecommunications Union (2015). 'ICT Facts and Figures 2015'. Geneva: International Telecommunications Union.

International Telecommunications Union (2015). 'Measuring the Information Society Report'. Geneva: International Telecommunications Union.

ITC (2015). 'International E-commerce in Africa: The Way Forward'. Geneva: International Trade Centre.

IRENA (2015). 'Africa 2030: Roadmap for a Renewable Energy Future'. Abu Dhabi: IRENA.

IRENA (2016). 'Solar PV in Africa: Costs and Markets'. Abu Dhabi: IRENA.

ISAAA (2014). 'ISAAA Brief 49-2014: Top Ten Facts'. Available at: www.isaaa.org/resources/publications/briefs/49/toptenfacts/default.asp (accessed 11 May 2017).

Jinging, M. (2017). 'Alibaba Cross-Border Drive into Russia'. Global Times, 21 February. Available at: www.globaltimes.cn/content/1034121.shtml (accessed 11 May 2017).

Kelly, T., and C. Kemei (2016). 'One Network Area in East Africa'. Washington, DC: World Bank. UNESCO (2016). 'YouthMobile’. Paris: UNESCO, Knowledge Societies Division.

Lai, F., L. Zhang, X. Hu, Q. Qu, Y. Shi, Y. Qiao, M. Boswell, and S. Rozelle (2013). 'Computer Assisted Learning as Extracurricular Tutor? Evidence from a Randomised Experiment in Rural Boarding Schools in Shaanxi'. Journal of Development Effectiveness, 5(2): 208-31.

Lendle, A., and P.-L. Vezina (2015). 'Internet Technology and the Extensive Margin of Trade: Evidence from eBay in Emerging Economies'. Review of Development Economics, 19(2): 375-86.

Liebreich, M. (2016). 'Keynote Address'. Bloomberg New Energy Finance, EMEA Future of Energy Summit. London, 10-11 October.

Mathews, J.A., and H. Tan (2014). 'Manufacture Renewables to Build Energy Security'. Nature, 513: $166-68$.

Nelson, A. (2015). 'Morocco Poised to Become Solar Superpower with Launch of Desert MegaProject'. The Guardian, 26 October. Available at: www.theguardian.com/environment/2015/oct/26/morocco-poised-to-become-a-solarsuperpower-with-launch-of-desert-mega-project (accessed 11 May 2017).

Newman, C., J. Page, J. Rand, A. Shimeles, M. Soderbom, and F. Tarp (2016). 'Made in Africa: Learning to Compete in Industry'. Washington, DC: Brookings.

Northern Corridor Transit and Transport Coordination Authority (2016). 'Towards Efficient Corridor Performance'. Northern Corridor Transport Observatory Report 8. Mombasa: Northern Corridor Transit and Transport Coordination Authority. 
Obulutsa, G. (2017). 'Kenya’s Lake Turkana Wind Power Scheme Readying for Production by End June'. Reuters, 18 January. Available at: www.reuters.com/article/kenya-electricityidUSL5N1F8167 (accessed 11 May 2017).

OECD (2016). 'Education at a Glance 2016: OECD Indicators'. Paris: OECD.

Parke, P. (2016). 'Kenya’s \$13 Billion Railway Project is Taking Shape'. CNN, 16 May. Available at: edition.cnn.com/2016/05/15/africa/kenya-railway-east-africa/ (accessed 11 May 2017).

Perez, N.D., and M.W. Rosengrant (2015). 'The Impact of Investment in Agricultural Research and Development and Agricultural Productivity'. Washington, DC: IFPRI.

REN21 (2016). 'Renewables 2016: Global Status Report'. Paris: REN21 Secretariat.

REN21 (2017). 'Renewables 2017: Global Status Report'. Paris: REN21 Secretariat.

Rodrik, D., (2016). 'Premature Deindustrialisation'. Journal of Economic Growth, 21(1): 1-33.

Sangwongwanich, P. (2016). 'Ma Says Next 30 Years Will Define Asia'. Bangkok Post, 11 October. Available at: www.bangkokpost.com/tech/local-news/1107265/ma-says-next-30-years-willdefine-asia (accessed 11 May 2017).

Scaturro, M. (2016). 'The New Space Race Signals Price Crash for Satellite Data'. Bloomberg, 22 September. Available at: www.bloomberg.com/news/articles/2016-09-22/too-manysatellites-means-sky-high-margins-under-pressure (accessed 11 May 2017).

SciDev (n.d.). 'Africa's Hydropower Future'. Available at: www.scidev.net/global/energy/datavisualisation/africa-hydropower-future-interactive.html\#section-1 (accessed 11 May 2017).

Scratch (2017). 'Statistics'. Available at: scratch.mit.edu/statistics/ (accessed 13 April 2017).

Sengooba, T., and J.J. Hakiza (n.d.). 'The Current Status of Late Blight Caused by Phytophthora Infestans in Africa'. Lima: CIP.

Sladoje, M. (2016). 'Lights Out: Zambia's Electricity Crisis'. Available at: www.theigc.org/blog/lights-out-zambias-electricity-crisis/ (accessed 11 May 2017).

Song, S. (2016). 'African Undersea Cables'. Available at: manypossibilities.net/african-underseacables/ (accessed 11 May 2017).

Soper, S. (2016). 'Amazon Cuts Delivery Times in Threat to Alibaba, EBay, Wish.com'. Bloomberg, 8 September. Available at: www.bloomberg.com/news/articles/2016-09-08/amazon-cutsdelivery-times-in-threat-to-alibaba-ebay-wish-com (accessed 11 May 2017).

Statista (2017). 'B2C E-commerce as Percentage of Global GDP from 2009 to 2018'. Available at: www.statista.com/statistics/324612/b2c-e-commerce-as-percentage-of-gdp-worldwide/ (accessed 11 April 2017).

Stone, G.D., and D. Glover (2017). 'Disembedding Grain: Golden Rice, the Green Revolution, and Heirloom Seeds in the Philippines'. Agriculture and Human V alues, 34(1): 87-102.

Support Precision Agriculture (2016). 'Laureates' Letter Supporting Precision Agriculture (GMOs)'. Available at: supportprecisionagriculture.org/nobel-laureate-gmo-letter_rjr.html (accessed 13 May 2017).

Swinnen, J., L. Zhang, H. Yi, Q. Qu, M. Boswell, S. Rozelle, and D. Mo (2013). 'Can One Laptop per Child Computing Narrow the Digital Divide and the Educational Gap in China? The Case of Beijing Migrant Schools'. World Development, 66: 14-29.

TechnoServe (2016). 'Domestic Remittances in South Africa'. Washington, DC: TechnoServe. 
Toyoma, K. (2015). Geek Heresy: Rescuing Social Change from the Cult of Technology. New York: PublicAffairs.

UNICEF (2016). 'Vitamin A Supplementation: A Statistical Snapshot'. New York: UNICEF.

USDA ERS (2017). 'International Agricultural Productivity: Summary Findings'. Washington, DC: United States Department of Agriculture, Economic Research Service. Available at: www.ers.usda.gov/data-products/international-agricultural-productivity/summaryfindings/ (accessed 11 May 2017).

Vaisala (2015). '5km Wind Available at: www.vaisala.com/Vaisala\%20Documents/Scientific\%20papers/Vaisala_global_wind_map. pdf (accessed 12 April 2017).

Werner, G. (2017). 'Liberia Has to Work with International Private School Companies If We Want to Protect Our Children's Future'. Available at: qz.com/876708/why-liberia-is-working-withbridge-international-brac-and-rising-academies-by-education-minister-george-werner/ (accessed 11 May 2017).

World Bank (2017). 'World Bank Indicators'. Available at: data.worldbank.org/indicator/IT.NET.USER.P2 (accessed 12 December 2016).

World Economic Forum (2016). 'Renewable Infrastructure Investment Handbook: A Guide for Institutional Investors'. Geneva: World Economic Forum. 